\title{
Luonnontieteen monta luontoa
}

Junan ikkunasta näkyy rivi kukkineita horsmia, jotka ovat levittäneet siemenensä kaiken maailman tuuliin. Oikealla, mihin juna liikkuu, ilmestyy näkyviin Malmin ostoskeskuksen pysäköintitalon varjo. Vasemmalla ikkunan puite peitti juuri asutuksen lomaan jääneen lehtomaisen, tervaleppää ja mesiangervoa kasvavan notkelman.

Maitohorsma, Chamaenerium angustifolium, Oenotheraceae-heimoon (horsmakasvit) kuuluva monivuotinen ruohokasvi. Erittäin yleinen. Tehokas leviäjä, joka tuottaa runsaasti siemeniä ja ilmestyy ensimmäisten kasvien joukossa metsäpaloaloille, hakkuuaukioille, suo-ojikoille sekä teiden varsille, ratapenkoille ja varastoalueille - siis ns. pioneerilaji. Vaatii avoimen kasvupaikan, ja siksi horsmakasvustot väistyvät ajan myötä muun kasvillisuuden, esimerkiksi tervaleppien ja mesiangervojen tieltä. Maitohorsma lisääntyy tehokkaasti myös kasvullisesti, juurakkonsa avulla. Juurakko voi sitkistellä pitkään hengissä varttuneessakin metsässä kehittäen vuosittain muutamia varjossa kituvia versoja, jotka eivät kuki koskaan. Seuraavan metsäpalon tai avohakkuun jälkeen juurakko ryöhähtää uudelleen kasvuun.

Positivismin aikakaudella 1800-luvulla eurooppalaiseen maailmankatsomukseen vakiintui tieteen ykseyden ihanne. Tieteellisen päättelyn yleisen mallin määritteli luonnontieteen silloinen edistynein muoto, newtonilainen fysiikka. Maailmankaikkeutta hallitsivat yhdenmukaiset lait, jotka voitiin systemaattisen havainnoinnin avulla paljastaa yksittäisten ilmiöiden taustalta. Metafysiikka, ilmiöiden olemukseen liittyvät spekulaatiot, pantiin lopullisesti viralta.

(Vaikuttaako liioittelulta kutsua 1800-lukua positivismin aikakaudeksi? Nojaudun tässä Maurice Mandelbaumiin, History, Man, \& Reason, The Johns Hopkins University Press, 1971.)

Mutta metafysiikkaa kammoavalla positivismilla oli oma metafysiikkansa (missä juuri metafysiikan kammo oli kantava ainesosa). Niinpä myös tieteen ykseyden ihanteen alla on lausumattomia olettamuksia. Näkemys "luonnon laeista" kiteyttää näistä oleellista. Klassiseen newtonilaiseen maailmankuvaan kuulunutta alkusäätäjää maallistuneet positivistit eivät enää ottaneet vakavasti, mutta luonnon vakaat lait toki pysyivät. Näiden joukkoon kohotettiin kehityksen (edistyksen) periaate, joka nivoi luonnon osat yhteen: Koko maailmalla on yhtenäinen, samoja lakeja noudattava historia. Luonto on ykseys. Luonnon lait paljastava tiede on siis välttämättä myös ykseys.

Comten tai Spencerin suureen systeemiin ja von Helmholzin tai Machin tieteenfilosofiaan jaksavat paneutua enää historian arkistojen ahkerimmat asukit, niin selvästi ne tuntuvat nykyaikana menettäneen merkityksensä. Eihän kukaan enää usko Comten "positiiviseen tietoon". Eihän kukaan ota vakavasti von Helmholzin yritystä johtaa tietoteorian periaatteet aistinelinten fysiologiasta. 
Mutta voimmeko olla varmoja, että Comten ja von Helmholzin, Spencerin ja Machin metafysiikasta on irtauduttu?

Puolentoista vuosisadan etäisyyden oikeuttaman jälkiviisauden turvin voimme sijoittaa varhaisen positivismin historiaan, eritellä sen suuntauksia ja kehitysvaiheita, erottaa sen taustoja 1700-luvun ajattelussa, jopa uumoilla sen perintöjä oman vuosisatamme loogisessa positivismissa ja tätä seuranneissa virtauksissa. Vaikeinta on kuitenkin arvioida ajattelun pohjalla olevia ja sitä jäsentäviä periaatteita. Ne pysyvät sitkeästi elossa, koska muuta vaihtoehtoa ei ole.

James Clerk Maxwell aloittaa dynamiikan perusoppikirjansa Matter and Motion (1877) fysiikan luonnehdinnalla: "Fysikaaliset tieteet ovat se tiedon osasto, jonka kohteena on luonnon järjestys, eli toisin sanoen tapahtumien säännöllinen seuraanto."

Maxwell kehittelee tätä seuraavasti: Yksinkertaisimmat luonnonilmiöt voidaan tulkita muutokseksi määrättyjen kappaleiden järjestyksessä. Kaikista ilmiöistä muutoksen mekanismia ei kuitenkaan vielä tunneta, sellaisistakaan, joiden taustalla tiedetään olevan kappaleiden järjestyksen muutos. Maxwell käyttää tästä esimerkkinä veden jäätymistä. Se ilmenee vesimolekyylien keskinäisen järjestyksen muuttumisena. Me ymmärrämme jäätymisen kun tiedämme, miten ja missä olosuhteissa veden molekyylien keskinäinen järjestys muuttuu. Veden jäätyminen on Maxwellilla havainnollinen esimerkki monimutkaisesta ilmiöstä, jota hallitsevien yleisten säännönmukaisuuksien selvittäminen on periaatteessa helppoa.

Veden jäätymistä voisi kuitenkin yhtä hyvin käyttää esimerkkinä periaatteessa yksinkertaisesta ilmiöstä, jonka yksityiskohtainen ennustaminen on mahdotonta. Yhdessä lumihiutaleessa voi olla esimerkiksi $10^{18}$ vesimolekyyliä. Olettakaamme, että joka miljardis näistä voi satunnaisesti vaihtaa sijaintiaan suhteessa muihin. Tuloksena on yli miljardi mahdollista virhettä, jotka voivat jakautua yhdessä lumihiutaleessa $10^{10,000,000,000}$ :lla eri tavalla. Jokaisella lumihiutaleella on ainutkertainen syntyhistoria.

Pidämme mielellämme Maxwellin tulkintaa näistä kahdesta mielekkäämpänä, koska yksittäisten lumihiutaleiden rakenteen ääretön vaihtelu on merkityksetöntä. Tämä pitäymys kannattaa kuitenkin ajatella loppuun asti: Miltä kannalta lumihiutaleiden vaihtelu on merkityksetöntä? Vastauksia on (ainakin) kaksi. Lumihiutaleiden loputon yksilöllisyys on yhdentekevää jalkakäytävää puhdistavalle talonmiehelle, jota kiinnostavat kinokset. Aineellisessa käytännössämme emme joudu tekemisiin yksittäisten lumihiutaleiden kanssa. Hiutaleiden rakennevaihtelu on yhtä lailla yhdentekevää fyysikolle, jota kiinnostavat jäätymisen yleiset rakenteelliset säännönmukaisuudet. Teoreettisessa käytännössämme emme pysähdy pohtimaan jokaista kohdalle osuvaa yksityiskohtaa.

Tästä ei kuitenkaan seuraa, että jäätymisfysikaalinen selitys olisi edessämme 
olevan lumihiutaleen ymmärtämiselle jotenkin perustavasti parempi tai oikeampi kuin kappalehistoriallinen selitys. Asetelma vaikuttaa lumihiutaleen kohdalla ehkä keinotekoiselta, mutta se muuttuu kiinnostavammaksi ajateltaessa luonnon ilmiöitä, joita on - tietämyksemme mukaan - olemassa vain yksi. Maailmankaikkeutta. Maapallon elämää. Maitohorsmaaa. Ihmistä. Tapahtumainkulkujen yksityiskohdat, kiemurat, käänteet ja yhteensattumat alkavat näyttää huomattavan mielenkiintoisilta verrattuna yleisiin säännönmukaisuuksiin. Yksittäiset (satunnaiset) tapahtumat sulkevat vaihtoehtoisia tapahtumia pois. Syntyy aitoja historioita, joissa aika on oleellinen ulottuvuus. Ainutkertaista historiaa selittävä juhlallinen yleistys on tyhjä.

Matkalla lumihiutaleesta maitohorsman historiaan olemme risteilleet tutulla reduktionismin ongelma-alueella: Voidaanko luonnon ilmiöiden selittäminen palauttaa rakenneosia kuvaaviin säännönmukaisuuksiin (veden jäätyminen molekyylien asetelmien muutoksiin)? Ongelma on vanhan positivismin peruja - ja tieteen ykseyden ihanteen kannalta vastaus on toki selvä ja painokas kyllä. Oman vuosisatamme looginen positivismi muotoili ongelman uudelleen ja kysyi, voidaanko tieteelliset teoriat loogiselta rakenteeltaan (yleensä) palauttaa yksinkertaisempiin alkeisosiinsa. Vastaus oli jälleen painokas kyllä.

Mutta lumihiutaleella on kahdet kasvot. Reduktionismin mielekkyys riippuu siitä, kumpaan niistä katsomme. Ehkäpä on ilmiöitä, joista on kiinnostavampaa selvittää yksityiskohtien vilinää ja tapahtumaketjujen satunnaisia solmuja kuin puhtaita yleisiä lakeja? Perinteinen reduktionismi pitää ilmiötä selvitettynä kun sen mekanismi on selvitetty. Tämä on kuitenkin vakuuttavaa vain, mikäli ilmiöllä ei ole historiaa. Luonnolla on historia.

On yksi asia osoittaa teoreettisen selityksen palauttaminen alkeisosiinsa loogisesti mahdolliseksi, mutta toinen asia väittää tämän olevan ainoa järkevä ja tieteellisesti perusteltu näkökanta.

$$
* * *
$$

Horsmakasvusto. Käymme laskemassa versot ja toteamme niitä olevan 274 .

Luku on sellaisenaan tutkimuksellisesti yhtä merkityksetön (tai merkittävä) kuin junan ikkunasta tehty satunnainen havainto. Tutkimuksellisesti kiinnostavaksi se muuttuu vasta, kun se kytketään johonkin horsmaa koskevaan ongelmaan ja tätä määrittävään teoreettiseen perinteeseen. Paljas luku muuttuu aineistoksi, ja sen olemassaolo saa uusia oikeutuksia.

Käsitystä yksittäisten havaintojen "teoriapitoisuudesta" (siis että omaksumamme teoriat ehdollistavat mitä havaintoja teemme) voidaan pitää kiistanalaisena, mutta aineistot ovat kiireestä kantapäähän teorioiden kyllästämiä — ilman teorioita aineistoilla ei ole mieltä eikä elämää.

Sama objekti voi olla erilaisena aineistona eri teorioille. 274 horsmanversoa. Kuinka kauan kasvuston kehitys on vaatinut? Mistä kasvuston ensimmäinen yksilö on peräisin? Kuinka monta erillisten juurakoiden yhteen sitomaa, geneet- 
tisesti erilaista yksilöä kasvustoon kuuluu? Kuinka laajalle versojen tuottamat siemenet leviävät ja kuinka monta uutta kasvustoa niistä on syntynyt? Ovatko Malmin radanvarren horsmat perinnöllisesti täsmälleen samanlaisia kuin hakkuualueiden horsmat, vai onko niissä eroja jotka voitaisiin luonnonvalinnan teorian nojalla tulkita sopeutumiksi erilaatuiseen ympäristöön?

Päteekö kaikkiin maitohorsmiin se, mikä pätee Malmin radanvarren maitohorsmiin?

Runsaasti jännittäviä kysymyksiä. Jokaiseen niistä vastattaessa luku 274 on kiinnostava, mutta jokaisessa tapauksessa eri tavoin. Kysymykset eriytyvät, ja "274" eriytyy. Yhteistä kaikille kysymyksille kuitenkin on, että emme tavoita niiden kohdetta muuten kuin muodostamalla luvusta 274 sopivan yhdistelmän joidenkin muiden lukujen kanssa (ja suhtautumalla yksittäisiin lukuihin suurella epäluulolla kuten yksittäisiin lukuihin tulee). Kyselemme ilmiöistä, jotka ovat olemassa vain teoreettisesti jäsentyneen aineiston välityksellä.

(Tosin versojen lukumäärä voi myös menettää merkityksensä kokonaan, jos esitämmekin kysymyksiä esimerkiksi horsmien anatomiasta, ravintofysiologiasta tai solukemiasta.)

Useimpiin kysymyksistämme ei tunneta vastauksia. Voimme silti kuvitella jatkokysymyksiä, esimerkiksi: Mikä on horsman merkitys lehtikuusen tai timotein ymmärtämiselle? (Kyllä kai yksi kasvi kertoo jotakin muista kasveista?) Mikä on horsman merkitys luonnon historian ymmärtämiselle? (Kyllä kai hyvin menestyvä laji kertoo jotakin niistä ympäristöistä, joissa sen evoluutio on tapahtunut?) Mikä on horsman merkitys urbaanin luonnon ymmärtämiselle? (Kyllä kai inhimillisestä toiminnasta hyötyvä laji jotenkin ennustaa inhimillisen toiminnan yleisiä ekologisia seurauksia?)

En lainkaan epäile, etteikö olisi mahdollista rakentaa loogisesti ja teoreettisesti aukoton ketju, joka kattaa kaiken alkeishiukkasista maitohorsmaan. En vain usko, että tällä on yhtään mitään merkitystä pohtiessamme niitä asioita, jotka ovat horsmassa mielenkiintoisia.

***

Teesi tieteen ykseydestä vaikuttaa maitohorsmien tutkimuksen käytännön kannalta merkityksettömältä. Kaikki kunnia galaksitutkimuksen tai laserfysiikan viimeisimmille saavutuksille, mutta ne antavat maitohorsmien ymmärtämiselle yhtä vähän kuin maitohorsmat niille.

Tieteen ykseys on saanut myös filosofian suunnalta iskuja, joista sen on vaikea toipua. Neljännesvuosisata sitten Thomas Kuhn osoitti, että (luonnon)tieteellä on aito historia, jonka kantavana lankana ei ole yksityiskohtien vähittäinen kasautuminen ("löydöt") vaan käsitteelliset murrokset, "vallankumoukset". Yksittäisen tutkimusperinteen piirissä tapahtuvan kumouksen jälkeen määrätty luonnonilmiö muuttuu täysin uuden näköiseksi. Kuhn päätyi epäilemään, että uuden ja vanhan teoriarakenteen täsmällinen vertaaminen on 
mahdotonta. Käsitteistöt ovat erilaiset - miten voimme tietää niiden puhuvan samasta asiasta?

Tieteenaloja on paljon ja erilaisia teoreettisia perinteitä niiden piirissä laskematon määrä. Eri aloja verrattaessa Kuhnin osoittama ongelma kärjistyy. Erilaisten (samanlaisten?) ongelmien teoreettisesti perustellut muotoilut ja näihin annetut, samojen teorioiden perustelemat vastaukset ovat ainoa, mitä meillä on. Keskenään ristikkäisten näkemysten ulkopuolelle ei ole pääsyä - ei ole objektiivista Arkhimedeen pistettä, josta käsin kilpailevia käsityksiä voitaisiin verrata.

Kuhnin tutkimuksissa on tieteellisten vallankumousten lisäksi toinen, vähemmän tunnettu juonne. Hänen mukaansa luonnontieteen eri tutkimusperinteet ovat jo menneinä aikoina olleet toisistaan paljon erillisempiä kuin yleensä esitetään. Erityisesti hän on korostanut eroa teoreettisten tieteiden ja kokeellisten tieteiden välillä. Puhdas teoria on ollut tieteen ihanne ja tieteen historia on kirjoitettu puhtaan teorian läpi, mutta tälle ei ole mitään syvällistä oikeutusta. Teoriat rakentuvat käytäntöjen varaan niistä riippuvaisina rakennelmina, joista filosofit ovat kautta aikojen pitäneet suhteettoman paljon melua. Suuret teoreettiset synteesit ja niiden vaihdokset kertovat lähinnä kulttuureista ja aikakausista, jotka ovat niitä tuottaneet.

Tutkimus on valtaosaltaan käytännöllistä askartelua tutkimusvälineiden, koejärjestelyjen ja muiden maallisten ongelmien parissa, ja tutkimuskäytännöt ovat toisistaan vielä eriytyneempiä kuin teoreettiset perinteet. Silloin tällöin tietenkin lainataan menestyksellisesti tutkimusmenetelmiä ja -välineistöjä alalta toiselle. Kemistien kehittämää automaattista analysaattoria voitaisiin esimerkiksi käyttää horsmanversojen solukemian tutkimiseen ja saada nokkelasti selville versojen geneettinen sukulaisuus. Tämä ei kuitenkaan muuta horsmien tutkimusta kemiaksi. Horsmanlehtien kemian analysointi on mielekästä vain jos se kytkeytyy kiinnostavaan horsmia koskevaan ongelmaan.

Maailmankaava ei sittenkään ole tieteen mielekäs tavoite vaan erinäisten selväpiirteisten ongelmien ratkaiseminen. Nämä voivat välittömästi liittyä käytännöllisiin tarpeisiin tai voivat olla liittymättä. Inhimillisten käytännöllisten tarpeiden arvioinnille tiedepolitiikan onnettoman kaavamainen luokittelu "sovellutuksineen" ja "tuotekehittelyineen" on ylimalkaan kelvoton. Mikäpä olisi "käytännöllisempää" kuin vaikkapa Aristoteleen etiikan hyvä elämä?

Miten hajautuva ja maallistuva tiede suhtautuu muihin inhimillisiin toimintoihin ja mielipiteisiin? Erinäisiä kysymyksiä tiede tietenkin ratkaisee paremmin kuin muut katsomukset. Erinäisten muiden kysymysten ratkaisussa tiede sen sijaan on moniin muihin katsomuksiin verrattuna täysin avuton (esimerkiksi Suomen kehitysapua edistäisi mittaamattomasti se, että johtavat virkamiehet liittyisivät joukolla kveekareihin). Tieteiden saavutuksia tulisi arvioida niiden todellisten kulttuuristen vaikutusten perusteella, ei ylihistoriallisista ihanteista käsin. 
Havaitsimme, että teorioiden ulkopuolella ei ole paikkaa, josta käsin teorioita voisi katsella. Mutta tästä seuraa, että teorioiden ulkopuolella ei myöskään ole paikkaa, josta käsin voisi katsella sitä mitä teoriat katselevat. Mitä siis on "luonto" verrattuna luonnosta puhuviin tieteisiin? Kun luonnontieteet hajoavat, niin hajoaako luonto mukana?

Voimme Ian Hackingiin (Representing and Intervening, Cambridge University Press, 1983) yhtyen pitää kiinni siitä, että teoriat ja niiden kohteet voidaan erottaa toisistaan. Teoriat tulevat ja menevät, ja niiden oikeellisuuden arviointiin ei ole niistä riippumatonta kiintopistettä. Teorioiden kohteet kuitenkin säilyvät. Siltamme niihin on tieteellinen käytäntö: kokeet ja manipuloinnit. Kyettyämme kokeellisesti vaikuttamaan atomeihin tiedämme atomeita olevan olemassa (mutta on täysin eri asia mitä teoriamme atomeista väittävät).

Siis kokeellinen käytäntö toimii siltana luontoon - mutta tässäkin on ongelma: Koetilanteet ovat konstruoituja. Mikä on kokeellisesti todennetun ilmiön merkitys siinä luonnossa jossa ei ole kokeilijaa? Koejärjestelyt voivat tuottaa tilanteita, joita ei ole milloinkaan aikaisemmin esiintynyt. Häkissä kasvanut gorilla voi loputtoman masennuksensa murtamana päivät pitkät paritella avaimenreikää, mutta kertooko tämä jotakin gorillan "luonnosta"?

Palaamme alkuun. Reduktionismi pakotti kysymään, mikä on mekanistisen yleistyksen merkitys ymmärrettäessä yksittäistä historiaa. Nyt kysymme, mikä on kokeellisesti konstruoidun yksittäisen tapahtuman yleistettävyys luonnon moniin historioihin. Onko "luonto" suuri laki vai luvuton määrä tapahtumaketjuja, enemmän tai vähemmän toisiaan muistuttavia?

$$
* * *
$$

Pian Malmin aseman jälkeen junan ikkunan eteen avautuvat Pukinmäen pellot. Ojien varsilla kasvaa tiheä pajukko. Kehä I:n valaisinpylvään päässä istuu varis. 